\title{
Practice and Exploration of "Micro Course" in Information Literacy Education
}

\author{
Jingshi Yang ${ }^{1, a^{*}}$ and Yanfeng Chen ${ }^{2, b}$ \\ ${ }^{1}$ Library, Tonghua Normal University, China \\ ${ }^{2}$ College of Mathematics, Tonghua Normal University, China \\ awenjianke2007@163.com, byfchenth@126.com
}

Keywords: Micro course; Subject service; Information literacy education; Reader training; University library

\begin{abstract}
The information literacy training service of university library is faced with the bottleneck of the complicated training content, the separation of learning and application for the training object, the poor effect of training application ability transformation and so on. The information literacy of micro course has the characteristic of "short, small, fine, live", not only can make up for the deficiency of traditional information literacy training services, but also is an effective way to enrich the content and form of the education for readers to demand. Tonghua Normal University library subject service team will search and use tips into knowledge units and make into a small series of micro course information resources, explores the beneficial practice in the training of reader service.
\end{abstract}

\section{Introduction}

With the arrival of micro era, micro learning has become an important learning model, micro training, micro reading, micro lectures, micro courses and other emerging ways to become an important carrier of this learning model. In order to keep up with the rhythm of the micro era, Tonghua Normal University Library (hereinafter referred to as our library) subject service team to use micro courses to provide teachers and students with the ability to enhance information literacy micro service.

\section{Bottleneck of Information Literacy Training in Universities}

Training Complex, Difficult to Grasp in the Short Term. After years of development, the information literacy course in university library is rich in content, from the layout of the library to infrastructure applications, from books classification rules to retrieval logic operator, from electronic journals, book retrieval to electronic theses acquisition methods, from the outside to the utilization of literature resources, from a single database using literature retrieval to document management, from office software skills to analysis software application, from the opening to the literature research paper writing skills, and so on, has formed a relatively complete system. University Readers are often eager to participate in the various types of information literacy training courses held by the library, but the readers who can learn and grasp the system are still a minority.

Separation of Learning and Application. The information literacy training of university libraries generally include: school of public elective courses, compulsory courses or lectures; library by semester cycle teaching; seminars, lectures training for faculty, subject or theme; training of freshmen, freshmen for basic training; embedded training, embedded subject, research team or professional courses using literature retrieval, analysis, management and training skills; database training and one-on-one instruction, etc.. These training methods are mainly based on the librarian teaching. although the university library information literacy training in various forms, content rich, systematic, but due to the limitation of time and space: on the one hand, the training time and the audience to participate in the study and research of the problems encountered in the process of time synchronization, the reader does not pay attention to these training in the absence of specific needs, and truly meet these problems and 
missed training; on the other hand, due to information literacy and readers' needs are different, the classroom teaching training very hard for the readers in the form and content.

Training Application Ability Conversion Effect Is Poor. Readers encountered in learning, teaching and research in the process of literature retrieval and utilization difficult, often unexpected turn to librarians, the effect is not ideal. The information literacy ability of mastery and ascension, only learn to use in order to achieve the best effect. Most readers want when they encounter problems, namely hand tools or methods available, so that the problem can be answered in a timely manner.

\section{Characteristics of "Micro Course" Service in Library}

Based on the problems found in the process of information literacy training of the above subject librarians, the library subject service team in our country began to try "micro course" service in information literacy training. library information literacy of micro course is based on the video dynamic subdivision of the knowledge point, short presentation of library resources and services, in-depth information retrieval and utilization of skills and information management and analysis tools, and other related knowledge. Library information literacy of micro course through the video form, so that the reader is not affected by time, space, content, limitation, you need to learn at any time, with micro contents, concise form; micro type, easy communication; strong scalability features etc.[1].

Diversity of Training Forms. The conventional library information literacy training includes library lecture series training, elective courses, training courses, embedded team training, one-on-one counseling training in a variety of ways, and the way of training in teaching. The use of micro course to carry out the information literacy training can be used as the extension and supplement of conventional library information literacy training courses, at the same time, because of its vivid, lively and attractive can also become readers' information literacy self promotion way.

Training Content Is More Practical. The knowledge point of library information literacy "micro course" is generally a subdivision of knowledge in literature retrieval, which is more practical and more targeted. If the knowledge system of the literature retrieval course is regarded as the face, then the micro course is the point, which has the characteristics of "short, small, fine, live", which is suitable for all stages of the school education and various types of courses [2]. "Short" refers to a short time, "small" refers to the selection of the theme of focus, "fine" refers to the knowledge points deep and valuable, "live" is lively, vivid and attractive.

Training Efficiency. Firstly, micro course breaks the limit of time and space, the reader can take advantage of fragmented time to learn. Secondly, the time of knowledge retrieval is changed from long to short, and the form is vivid and lively. It is convenient for readers to use the time of fragmentation to study, and make the readers learn easily and happily. Thirdly, the micro course is also applicable to mobile phones and other mobile terminal mobile learning, is the extension of classroom learning. Therefore, the use of micro courses to enhance the reader's information literacy ability makes the training efficiency is higher, the effect is better.

\section{"Micro Course" Tool Selection and Production Skills}

There are many kinds of micro course recording tools, such as Camtasia Studio, screen video experts and Web Ex and other mainstream video editing software. What kinds of tools are mainly based on the functions of different tools and the usage of the librarians.

I found in the tools of the survey, due to speed and other reasons, direct recording of the actual operation of the process will have varying degrees of delay, and the operating speed is not good grasp. Therefore, I use the contents of the museum to make the PPT direct output WMV video or video recording software through the screen to make the video micro course, which makes it easier for librarians to operate. "Micro course" production skills need librarians meticulous experience and accumulation, I share the following points: (1) design page: the establishment of a unified style, design team, update time and copyright; (2) screenshot: in order to make the screenshot clear, you should first adjust the scale of the page, the text on the picture should be as much as possible to enlarge the 
screenshot; (3) text: through the description of the main content of the label, the title of the section is not less than the number of 36 , the text is not less than the size of the number of 28 ; (4) length control: the length of the micro video control within 10 minutes, the page stay time not less than 5 seconds, more pages of text content need to stay longer, in order to ensure that readers understand the content of the page; (5) make full use of the animation, sound effects and color matching of PPT software to enhance the recording and display effect of micro course.

\section{"Micro Course" Service Promotion Strategy}

In order to make the library information literacy "micro course" to play a greater role, our library in the following ways to carry out extensive publicity in the reader.

Internal Channel Promotion. (1) Released by the library official WeChat public platform [3]. The next semester in 2016, the museum through the official WeChat public platform releases 8 Tonghua Normal University library series micro course, released weekly; (2) publish through the subject service platform[4]. Under the subject of information technology, Tonghua Normal University, "information literacy" module with micro course column, which brings together a variety of subjects related to micro courses for students to enhance the subject of information literacy to provide support.

External Channel Promotion. (1) Through the staff mailbox, as well as Sina, campus forums and other channels to release "micro course"[5]; (2) on the homepage of the university website, the links of the subject service platform and the entrance of the "micro course" is used, and the interaction between the librarians, the teachers and the students should be strengthened; (3) organized student activities: the organization of professional literature retrieval tools and application skills of micro course contest, collect the information literacy of the teachers and students experience in the research process and skills, improve information literacy ability to create atmosphere, promote exchanges[6]; (4) subject librarians to join the various types of teachers and students QQ group, to carry out weekly micro video service[7].

Guide Teachers and Students in the Course of the Use of "Micro Course". (1) Subject librarians collect common consulting questions and make them into micro video, and promote micro video in the process of consulting service; (2) subject librarians introduce the "micro course" in the information literacy training service of the embedded professional courses to enhance the activity of the course; (3) subject librarians promote micro courses in the process of resource push service".

\section{"Micro Course" Service Practice Effect}

Exert a Subtle Influence on Teachers. Teachers' information literacy is one of the most important criteria for the development of school information. Through the investigation, we know that the literature collection work in the process of scientific research is mostly done by students. Some teachers because of teaching and research tasks heavier, do not have too much energy to pay attention to or master the use of more literature skills, literature retrieval, utilization, management and analysis. From the point of faculties, teachers also hope that through the application of information technology to enhance the ability to enhance the teaching ability and effectiveness. The library service team to use "micro course" for teachers to provide "micro training" and "micro service" [8]. On the one hand, the subject service team through a series of marketing tools will be micro courses pushed to the teacher's desk, allowing teachers to understand the subtle, attention or learning skills. On the other hand, for teachers to carry out resource push service, SDI, embedded training service, the "micro course" as auxiliary means to expand the service content, such as "how to track the latest progress of literature", "literature management software application" and "literature analysis and use", in order to achieve to assist teachers to enhance information literacy ability.

Promote the Combination Learning and Autonomous Learning, then Promote Students' Information Literacy. In the course of subject service, on the one hand, it is the way to promote librarians learning, so that students can use the "micro course" to learn the relevant knowledge and improve their information literacy. In the information literacy training course, "preheat link micro course" as the course content, questions in the "micro course", let students classroom learning with 
questions; in addition, the classroom theme outside the search methods and skills as micro course class knowledge training, let students learn for more information on using skills. On the other hand, the way of students' autonomous learning can be obtained at any time when students encounter problems, so as to make them know how to get help and study. The combination of the two ways to promote the improvement of students' information literacy.

Improve Quality of Librarian Teaching Benefits Teachers as Well as Students. In the selection of micro course knowledge and classification process, librarians must be not only familiar with the knowledge, skills and methods of retrieval needed by readers, but also understand and service resources, tools and methods available in the university library, the two together in order to design a "micro course"value. In the design and production of micro course, librarians should not only be skilled in the application of PPT, but also have the ability of design and creativity [9]. Teachers and students in the literature information retrieval skills "micro course" collection activities, the teachers, the students and the librarians experience and creativity is not only a kind of inspiration, but also a knowledge update and information literacy ability to enhance learning.

\section{Conclusion}

At present, the university library application of "micro course" services to carry out the information literacy education is still in the initial stage, the quantity and quality of the information literacy of micro course also needs to constantly increase and improvement in knowledge division, knowledge system planning also needs to continue to explore and summarize the experience. As for the university library, the reader's information literacy ability needs to have the common character, and it is also the important function of the library to improve the reader's information literacy ability. Therefore, universities can cooperate in the development of micro course platform or micro library establishment [10], information literacy to achieve micro course sharing and exchange of experience.

\section{Acknowledgements}

This work was financially supported by"The practice and exploration of micro course in information literacy education (JY2016027) ", which was approved by Tonghua Normal University as "the higher education teaching reform research project".

\section{References}

[1] L. X.Qing: Discussion on the application of micro course in Library. Information Exploration, Vol.14 (2014) No.10, p. 106-108.

[2] Z.J.Ran: Overview of micro courses . China Information Technology Education Vol.5 (2012) No.12, p. 19-21.

[3] Information on http://www.lib.thnu.edu.cn/news.jsp?id=844.

[4] Information on http://librarian.lib.thnu.edu.cn/.

[5] Y.X.Jiao, L.J.Zhou and Z.F.Lun: Construction of information literacy education in universities micro class platform. National Library Research Journal, Vol.10 (2014) No.4, p. 70-74.

[6] S.H.Dan and X.Yi:To explore the teaching mode of micro teaching of literature retrieval. Journal of Library, Vol.26 (2014) No.7, p. 114-116.

[7] Y.X.Jiao: Study on the construction of $\mathbf{J}$ information literacy education in universities micro class platform. The National Library of China, Vol. 38(2014) No.4, p. 15-18.

[8] P.Y.Tao and W.Liao: The information literacy education for university students "MOOC" trend. University Library Journal, Vol.13 (2014) No.4, p. 21-27. 
[9] H.H.Hua: the change of information literacy education under the background of MOOC. Knowledge of Library and Information Science, Vol.60 (2015) No.4, p. 14-25.

[10] G.W.Wei: Study on the ecological environment of micro information in Library. Journal of Library and Information Science, Vol.58 (2013) No.6, p. 16. 